\title{
Environmental awareness and green products consumption behavior: A case study of Sabah State, Malaysia
}

\author{
SARIMAH SURIANSHAH \\ Faculty of Science and Natural Resources, Universiti Malaysia Sabah, Jalan UMS, 88400, Kota Kinabalu, Sabah, Malaysia \\ email: sarimah.surianshah@ums.edu.my
}

Manuscript received: 30 April 2021. Revision accepted: 13 June 2021

\begin{abstract}
Surianshah S. 2021. Environmental awareness and green products consumption behavior: A case study of Sabah State, Malaysia. Biodiversitas 22: 2685-2692. The severe weather changes in the Sabah state of Malaysia have raised a great concern for us to address it through environmental awareness. Addressing the problem is important because Sabah is one of the main tourist destinations in Malaysia with its beautiful biodiversity, flora and fauna. Hence, this paper examines the level and relationship between environmental awareness and green product consumption behavior in Sabah. Here, we mainly measure environmental awareness using proxies of awareness towards climate change issues. A systematic questionnaire survey was conducted to 300 respondents of Sabah, including Tawau, Lahad Datu, Sandakan, and Kota Kinabalu. The descriptive statistics results show that people in Sabah have a high level of environmental awareness and green product consumption. In particular, they aware to conserve and preserve the tropical rainforest ecosystem and consume green products for future generations benefits. However, to note that there is still a low Sabahan's awareness about impact of overuse of natural resources and the importance of consuming green products in daily life. The estimate of the relationship between both variables shows a positive and statistically significant effect, especially in Kota Kinabalu. Also, the effect is pronounced when we address potential endogeneity bias in the baseline model. This study suggests that the government, policymakers, and youngsters continuously spread the benefits of green product consumption. This is because an increase in environmental awareness possibly helps mitigate environmental issues and lead to better biodiversity conservation and economic improvement in Sabah and Malaysia.
\end{abstract}

Keywords: Biodiversity, environmental awareness, green products consumption, Sabah, policymakers

\section{INTRODUCTION}

The Environmental Performance Index (EPI) is an instrument to examine environmental performance in many countries (Wendling et al. 2020a). It was conducted by Yale University who ranks 180 countries based on 11 environmental issue categories, namely air quality, sanitation and drinking water, heavy metals, waste management, ecosystem services, biodiversity and habitat, fisheries, climate change, pollution emissions, water resources, and agriculture. The data was collected from various entities such as international governing bodies, independent organizations, and academic research centers. On average Malaysia, environmental performance shows a decreasing rank from $9^{\text {th }}$ position in 2006 to $68^{\text {th }}$ in 2020 . Table 1 illustrates Malaysia aggregate EPI scores compared to other Southeast Asian countries. Currently, Malaysia EPI score was 47.9, with a slight increment score compared to a decade ago. Malaysia was ranked third compared to other Southeast Asia countries but ranked $68^{\text {th }}$ compared to the 180 countries. Its ranking worsened compared to $9^{\text {th }}$ position in 2006. Regarding environmental issues, Wendling et al. (2020b) report that two issues that contributable to Malaysia EPI scores changes are: i) climate change and ii) biodiversity and habitat. Hence, it is an indicator for researchers to address them in order to reduce environmental issues in Malaysia.
Table 1. Environmental Performance Index (EPI): Malaysia versus other Southeast Asia countries

\begin{tabular}{lll}
\hline Country & EPI score & 10-year change \\
\hline Malaysia & 47.9 & 4.4 \\
Indonesia & 37.8 & 4.1 \\
Vietnam & 33.4 & 5.4 \\
Philippines & 38.4 & -4.1 \\
Thailand & 45.4 & 4.1 \\
Singapore & 58.1 & -8.4 \\
Myanmar & 25.1 & -1.2 \\
Laos & 34.8 & -2.8 \\
Cambodia & 33.6 & -0.2 \\
Brunei Darussalam & 54.8 & 2.0 \\
Timor-Leste & 35.3 & -3.0 \\
\hline Source: Wending et & $(2020) . \mathrm{Not}: S c a l$ from $0-100, \mathrm{fr}$
\end{tabular}

Source: Wendling et al. (2020a). Note: Scale from 0-100, from worst to best performance

This study focuses on examining environmental issues in Sabah, a state of Malaysia. Recently, in 2016, Sabah faced a great climate change called, El Nino phenomenon. Besides that, Sabah faces quick and unpredictable weather changes regularly (Wen and Sidik 2011; Yusof 2021). It generally, caused drought season and increased in temperature which affects greatly the state's economic production such as on agriculture and fisheries (Wen and Sidik 2011). According to the World Economic Forum, increasing phenomena such as natural disasters and severe 
weather resulted from failure of climate-change mitigation and adaption (World Economic Forum 2021). It poses an urgent challenge in particular for the Intergovernmental Panel on Climate Change (IPCC), the Malaysian Ministry of Environment and Water, the Ministry of Science, Technology \& Innovation, and the Ministry of Water, Land and Natural Resources, among others, to encounter future risks of climate change. Malaysian government bodies have been introduced several measures to lessen the issue and one of the measures is to improve public awareness of the environment by empowering the use of green products.

In this study, we expect that empowerment in green product consumption behavior positively contributable to improvement in environmental awareness among the public. This hypothesis is in line with the utility maximization theory which suggests that consumers decide to spend their money to yield better preferences. Many previous studies show the positive relationship between environmental awareness and green product consumption behavior such as Rustam et al. (2020) in Pakistan and Xu et al. (2020) in China. However, a limited study has been conducted in Malaysia, in particular the Sabah state context. Sabah is the second largest state in Malaysia and among the top destination to visit in Malaysia. It is rich in beautiful flora and fauna. Thus, it makes it important for relevant research to be carried out to protect the state's biodiversity and indirectly mitigate environmental issues.

In Malaysia, the Green Technology Master Plan (GTMP) and organizations that support the green campaign are among stimulators to educate Malaysian about the importance of green product consumption. However, its effect on environmental awareness is still ambiguous- particularly in Sabah. Green products or sustainable products are known for their environmentally, socially, and economically friendly features. Belz and Peattie (2012) suggest that green products should satisfy its customer; focus on ecological and social significance; environmentallyfriendly; provide socio-ecological improvement; possess continuous improvement; and offer competition to other products. These may be among potentials factors to boost an individual intention to consume green products. However, we expect a reverse causality effect maybe happens in the baseline model where environmental awareness may affect individual green product consumption behavior as found in Ojo and Fauzi (2020). Hence, in this study, we also aim to tackle the problem by addressing potential endogeneity bias in the model estimates. To the best of my knowledge, no study addresses this issue. In the next section, we will discuss the materials and methods of this study including the study area, research design to address the issue and data analysis explanation. It is followed by results and discussion section and ended with concluding remarks and suggestions for further studies.

\section{MATERIALS AND METHODS}

\section{Study area}

The study was conducted in Sabah, a state of Malaysia. It was located in the northern portion of Borneo and East Malaysia. Figure 1 shows our areas of study which covered only the major areas of Sabah, namely Tawau, Lahad Datu, Sandakan, and Kota Kinabalu.

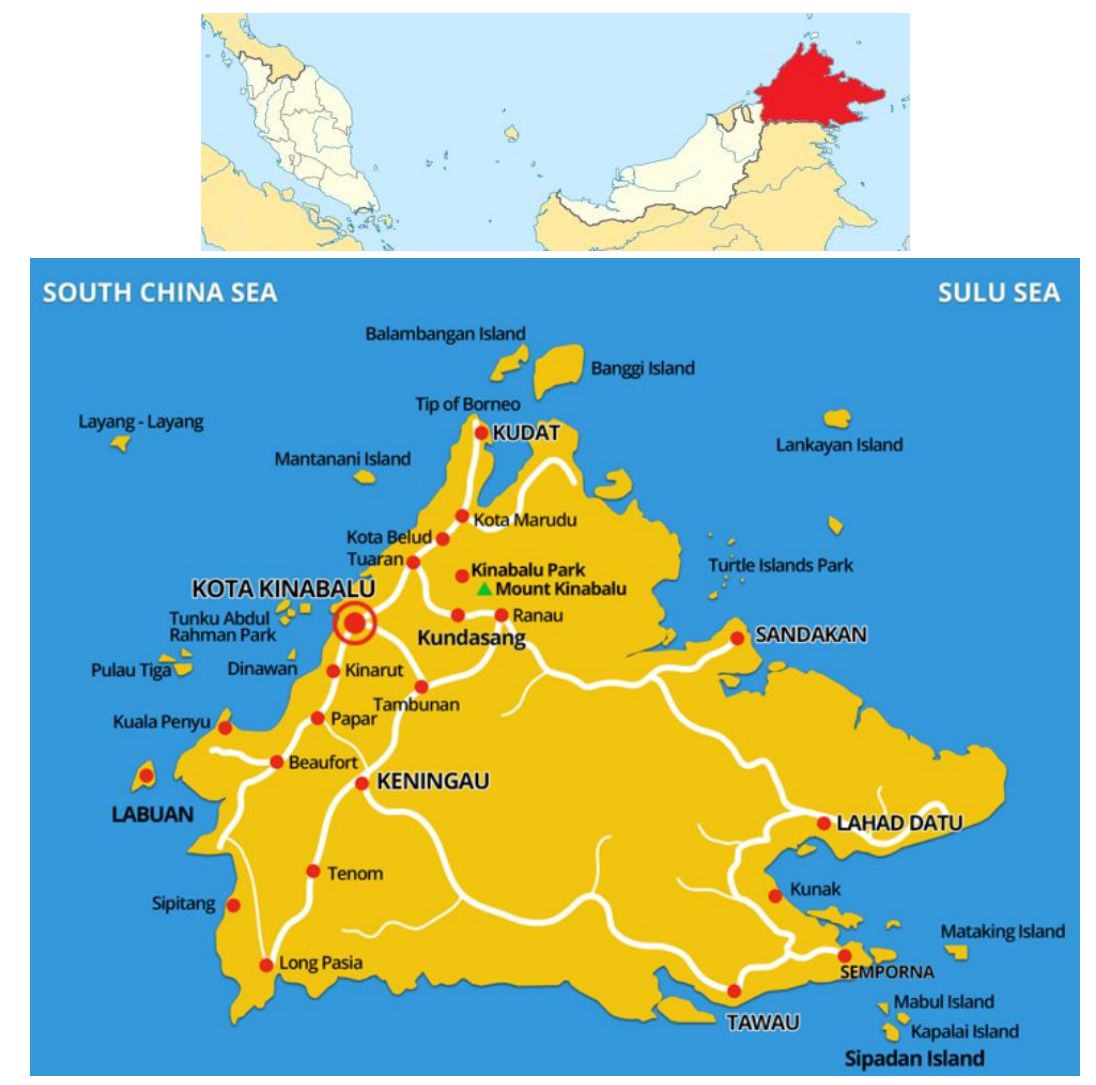

Figure 1. Sabah map. Source: Official Website of the Sabah State Government 
Table 2. Cronbach alpha results

\begin{tabular}{lll}
\hline Section & Cronbach alpha & No.of items \\
\hline A & 0.631 & 5 \\
B & 0.600 & 10 \\
C & 0.688 & 10 \\
D & 0.741 & 6 \\
\hline
\end{tabular}

Tawau is the third-largest city in Sabah, after Kota Kinabalu and Sandakan, with a population of 142,900 people in 2017 based on the report by the United Nations. Its main economic activity is fisheries, the same as Lahad Datu. Lahad Datu is a district located approximately 149 kilometers $(\mathrm{km})$ from Tawau, $154 \mathrm{~km}$ from Sandakan, and about $500 \mathrm{~km}$ from the capital city of Sabah, Kota Kinabalu. Next, Sandakan is one of the places rich in nature that attracts many foreign and local tourists to Sabah. It is synonyms with the meanings of its parts of name "San" which means "Sea, Adventure, And Nature". Sandakan economic activities include fisheries, tourism, and bird nests. Lastly is the capital city of Sabah, Kota Kinabalu. It is located on the west coast of Sabah. Previously, it was known as Jesselton before renamed Kota Kinabalu in 1967. It is Sabah's main tourist destination with beautiful features of biodiversity.

\section{Research design}

A systematic approach to design the research has been conducted. First, a pilot study was conducted to test the validity and reliability of the survey. The Cronbach alpha values were calculated and all results had fulfilled the requirements (Table 2). The Cronbach alpha values greater than 0.6 is acceptable (Sekaran and Bougie 2014). Then, the sample was randomly selected from the four study areas which consist of approximately 612,000 total populations. We follow Krejcie and Morgan (1970) sample size determination rules at a $90 \%$ confidence interval and need the study to collect at least 271 samples. A total of 300 respondents was randomly selected from urban and rural areas of the study. 33 per cent of the respondents from Tawau, 26.7 per cent from Kota Kinabalu, 23.3 per cent from Lahad Datu, and 16.7 per cent from Sandakan.

The questionnaire and dataset were obtained from Liwan et al. (2019). It consists of four sections-A, B, C, and D. Section A covers respondents demographics questions. Sections B and C cover this study's main interests which are the level of environmental awareness (climate change) and green product consumption. They were scaled into 5-point Likert scale questions (from strongly disagree to strongly agree). Lastly, Section D includes two parts: part one consists of binary questions and part two consists of 5-point Likert scale questions concerning respondents' awareness of government policy on green technology and climate change. Detailed questions included in the questionnaire are available in the results and discussion section.

\section{Data analysis}

First, a descriptive analysis was conducted in this study to present the level of environmental awareness among the respondents as well as their behavior towards green product consumption. The mean value was calculated and the results were presented using figures.

Next, further analyses were conducted. First, using a simple ordinary least squares (OLS) method to examine whether there is a relationship between green product consumption and environmental awareness. Gujarati and Porter (2008) show that ordinary least square is a statistical technique to describe the relationship between two variables. We are also able to examine the effect size from the method. Second, using a two-step least squares (2SLS) method to examine if there exists an attitude-behavior gap of green product consumption in Sabah -possible endogeneity effects. Following the extended theory of planned behavior by $\mathrm{Xu}$ et al. (2020), we expect that an individual behavior towards green product consumption practices is perceived from his/her attitudes towards it.

The OLS model at individual level can be written as follows:

$$
A=\alpha_{0}+\alpha_{1} G+\beta_{j} D_{j}+\mu
$$

Where: $A$ is the measure of an individual aggregate environmental awareness, is the vector of green product consumption behavior. $D$ is the vector of control variables such as study areas, an individual's demographics, and awareness of government policy related to the environment. is an error term. Here, we treated the ordinal variables with the 5-Likert scale as a continuous variable following Williams (2020).

Whereas, the 2SLS model can be written as follows:

$$
A=\alpha_{0}+\alpha_{1} X+\alpha_{2} \widehat{G}+\cdots+\alpha_{j} X \mu
$$

Where is an endogenous variable, purchasing green products consumption behavior, and is the predicted result from the following first-stage estimate of Equation (3):

$$
\widehat{G}=\delta_{0}+\rho_{k} Z_{k}+\delta_{1} X+\gamma_{j} D_{j}+\varepsilon
$$

Where for $k=1, \ldots, \mathrm{q}$ are the instruments for the consumption behavior, that is the green product consumption expectation and beliefs.

To check the validity of this method, I look at the significance of the Wu-Hausman F-statistics (Hausman 1978; Wu 1974), the F-statistics of first-stage regression of Equation (3), and the Sargan's (1958) statistics. The WuHausman F-statistics shows the validity of the causal variable of interest, whether it is endogenous or not, and hence ensures whether the baseline model of Equation (1) yields biased estimates or not. Both the F-statistic of the first-stage regression and the statistics indicate the strength of the instruments. A not weak instrument is the instrument that is highly correlated with the endogenous variable or 
satisfies Stock et al.'s (2002)suggestion of an F-statistic that should exceed ten to be reliable when there is one endogenous regressor. Recently, Hahn and Hausman (2002) suggest that instruments are strong when the null hypothesis cannot be rejected: the null hypothesis is that the instruments are weak. For an analysis with more than one instrument, I check on the over-identifying restrictions test of Wooldridge's robust score test. This tests whether the instruments are uncorrelated with the structural error term in Equation (1). It also identifies whether our IV model is misspecified and if one or more of the excluded exogenous variables should be included in the structural equation.

\section{RESULTS AND DISCUSSIONS}

This section first presents the results of the descriptive statistics of environmental awareness and green product consumption following some discussions. We then report the estimated results of the relationship between the two variables and their discussions.

Figure 2 shows the responses from respondents to environmental awareness proxies: i) replanting trees help to reduce climate change; ii) deforestation causes climate change; iii) overuse of natural resources causes climate change. Regarding overuse of natural resources such as water, air, land, flora and fauna, causes climate change, majority of the respondents (52.33 percent) agree with it. Almost one-fourth of the respondents strongly agree with the statement, and the remaining tend to not agree. However, to note that the proportion of respondents who had chosen disagree for this proxy is higher than other proxies. It suggests that there is still less environmental awareness of respondents when measured using this proxy.

Next, both proxies, which are deforestation causes climate change and replanting trees would help to reduce climate change show a better proportion towards the "agree" options. About $90 \%$ of the respondents at least chose agreed on the deforestation option. It suggests that people in Sabah are aware of the importance of conserving their tropical rainforest and, consequently, environment. It implies that the effects of human activities from deforestation such as an increase in temperature and acid rain and haze can be mitigated. This might be due to the positive impacts of the government and institutions campaign, such as using recycled paper and stopping printing and going paperless. In addition, this finding is in line with the attempt of OECD on introducing the Reducing Emissions from Deforestation and Degradation
(REDD) policies in developing countries. Among the REDD objective are to mitigate climate change and protect biodiversity (Peterson et al. 2012). Review papers by Dulal et al. (2012) and Samii et al. (2014) stressed that effective and successful REDD project outcomes in less developed regions are those with a clear formula of design; governance, land tenure rights and capacity; equity and transparency; indigenous peoples' right and knowledge; local-international cooperation; and empowerment of local and institutional capacities. These measures are recommended to be considered in any plan as the policy is not cost-effective. In addition, the rate of deforestation coincides with the level of economic growth in certain regions as explained by the environmental Kuznets curve (EKC) (Cole et al. 1997; Stern 2004; Culas 2007; Suki et al. 2020).

The replanting trees program introduced through the government and non-government institutions such as Rubber Industry Smallholders Development Authority (RISDA) and Universiti Malaysia Sabah (UMS) also positively impacts people's awareness of the importance of the environmental protection measures. A significant number of people show a high-level awareness of the measures and imply the relevance of the continuation of the program. In Malaysia as a whole, the recent Kempen Penanaman 100 Juta Pokok 2021-2025 should be boosted as it may help to protect the environment. In regards to Sabah position as Malaysia's largest and growing state of palm oil production (Martin et al. 2015), a few studies show the importance to replant palm oil to conserve biodiversity and the environment. However, strategic actions should be taken to ensure both economy and biodiversity are protected optimally by taking several actions such as cutting down and replanting palm oil at appropriate ages (Snaddon et al. 2013).

The level of green product consumption behavior is explained based on three aggregate levels. Here, we categories the Likert scale of Table 3 into three levels namely: (i) high-level (strongly agree or agree); (ii) moderate-level (less agree); (iii) low-level (strongly disagree or disagree). Table 3 shows that item (1) that shows green products are not optional products, is categorized as a low-level consumption behavior and need more efforts to cultivate it, whereas items (2), (4), and (5) show a high level of green consumer behavior and corresponding with the consumer behavior theory by Deaton and Muellbauer (1980), who assume that customers are rational. Only item (3) is categorized as a moderate level consumption behavior.

Table 3. Questions on green products consumption behavior

\begin{tabular}{clccccc}
\hline Items & Green products are: & Strongly agree & Agree & Less agree & Disagree & Strongly disagree \\
\hline 1 & Not optional products & $1.67 \%$ & $12.67 \%$ & $35.33 \%$ & $32.67 \%$ & $17.67 \%$ \\
2 & A good investment for future generations & $32.00 \%$ & $51.67 \%$ & $13.67 \%$ & $1.67 \%$ & $1.00 \%$ \\
3 & An environment-friendly product & $19.67 \%$ & $46.00 \%$ & $30.67 \%$ & $2.32 \%$ & $1.33 \%$ \\
4 & Consumer preference products & $27.67 \%$ & $50.00 \%$ & $21.67 \%$ & $0.67 \%$ & $0.00 \%$ \\
5 & Affordable compared to others & $0.00 \%$ & $6.33 \%$ & $34.33 \%$ & $35.33 \%$ & $24.00 \%$ \\
\hline
\end{tabular}




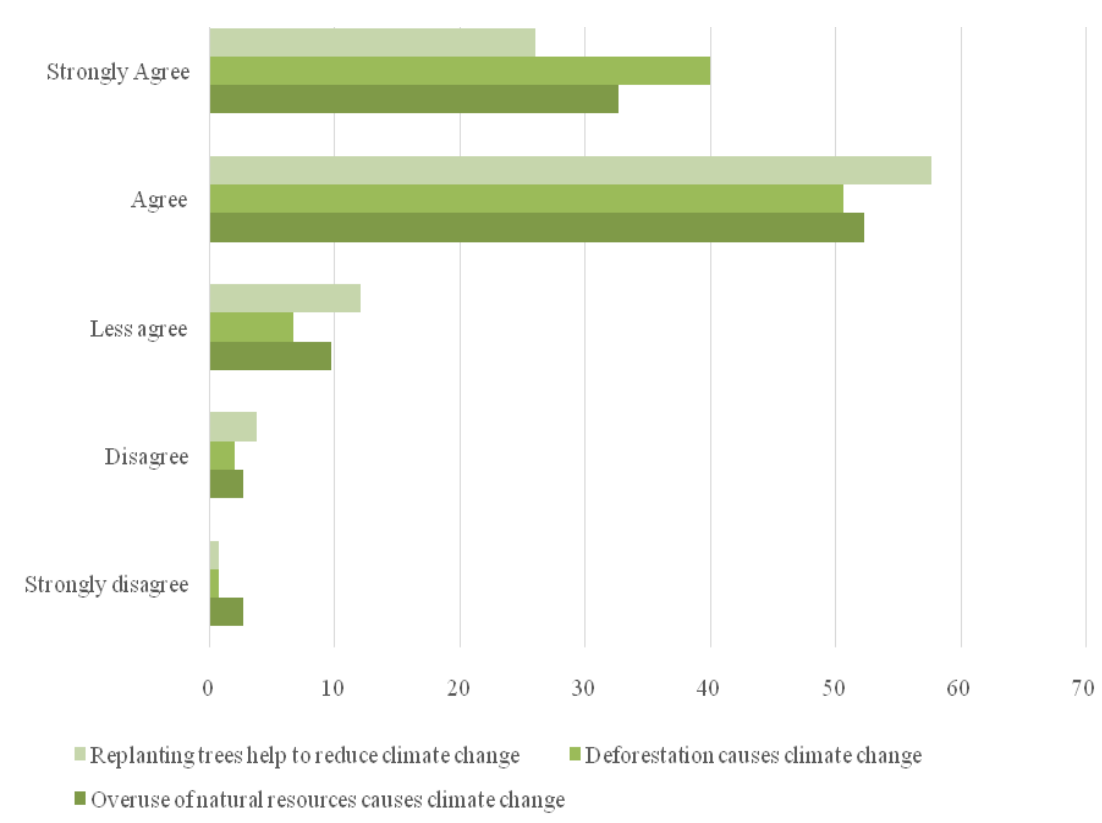

Figure 2. Questions on environmental awareness on nature preservation and climate change

Table 4. Estimates of relationship between green products consumption and environmental awareness

\begin{tabular}{|c|c|c|c|c|c|}
\hline \multirow{2}{*}{$\begin{array}{l}\text { Dependent variable: } \\
\text { Environmental awareness }\end{array}$} & (1) & (2) & (3) & (4) & (5) \\
\hline & All sample & Tawau & Lahad Datu & Sandakan & Kota Kinabalu \\
\hline Green products consumption & $\begin{array}{l}0.322^{* * * *} \\
(0.110)\end{array}$ & $\begin{array}{l}0.301^{* *} \\
(0.127)\end{array}$ & $\begin{array}{l}0.075 \\
(0.136)\end{array}$ & $\begin{array}{l}0.127 \\
(0.356)\end{array}$ & $\begin{array}{l}0.773^{* *} \\
(0.317)\end{array}$ \\
\hline Government policy & $\begin{array}{l}0.219^{* *} \\
(0.091)\end{array}$ & $\begin{array}{l}0.305 \\
(0.191)\end{array}$ & $\begin{array}{l}0.142 \\
(0.091)\end{array}$ & $\begin{array}{l}0.319 \\
(0.263)\end{array}$ & $\begin{array}{l}0.520^{* *} \\
(0.257)\end{array}$ \\
\hline \multicolumn{6}{|c|}{ Age groups (base: below 20 years) } \\
\hline $20-30$ years & $\begin{array}{l}-0.014 \\
(0.127)\end{array}$ & $\begin{array}{l}0.399 \\
(0.246)\end{array}$ & $\begin{array}{l}-0.179 \\
(0.231)\end{array}$ & $\begin{array}{l}0.286 \\
(0.401)\end{array}$ & $\begin{array}{l}0.387^{*} \\
(0.230)\end{array}$ \\
\hline $30-40$ years & $\begin{array}{l}-0.056 \\
(0.150)\end{array}$ & $\begin{array}{l}0.255 \\
(0.295)\end{array}$ & $\begin{array}{l}-0.525^{* *} \\
(0.259)\end{array}$ & $\begin{array}{l}0.353 \\
(0.483)\end{array}$ & $\begin{array}{l}0.850^{* * *} \\
(0.324)\end{array}$ \\
\hline 40 years and above & $\begin{array}{l}-0.047 \\
(0.168)\end{array}$ & $\begin{array}{l}0.158 \\
(0.350)\end{array}$ & $\begin{array}{l}-0.384 \\
(0.297)\end{array}$ & $\begin{array}{l}0.568 \\
(0.582)\end{array}$ & $\begin{array}{l}0.346 \\
(0.360)\end{array}$ \\
\hline Male & $\begin{array}{l}-0.043 \\
(0.055)\end{array}$ & $\begin{array}{l}0.194^{*} \\
(0.106)\end{array}$ & $\begin{array}{l}-0.024 \\
(0.128)\end{array}$ & $\begin{array}{l}-0.036 \\
(0.169)\end{array}$ & $\begin{array}{l}-0.224^{* *} \\
(0.110)\end{array}$ \\
\hline \multicolumn{6}{|l|}{ Marital status (base: single) } \\
\hline Married & $\begin{array}{l}-0.172^{*} \\
(0.088)\end{array}$ & $\begin{array}{l}-0.031 \\
(0.112)\end{array}$ & $\begin{array}{l}0.050 \\
(0.166)\end{array}$ & $\begin{array}{l}-0.662^{* *} \\
(0.262)\end{array}$ & $\begin{array}{l}-0.323 \\
(0.202)\end{array}$ \\
\hline Single-parent & $\begin{array}{l}-0.269^{*} \\
(0.148)\end{array}$ & 0.000 & $\begin{array}{l}-0.628 \\
(0.382)\end{array}$ & 0.000 & $\begin{array}{l}-0.128 \\
(0.468)\end{array}$ \\
\hline Others & $\begin{array}{l}-0.292^{* * *} \\
(0.143)\end{array}$ & & & & $\begin{array}{l}-0.392 \\
(0.254)\end{array}$ \\
\hline Lahad Datu & $\begin{array}{l}0.145^{* * *} \\
(0.062)\end{array}$ & & & & \\
\hline Sandakan & $\begin{array}{l}0.087 \\
(0.087)\end{array}$ & & & & \\
\hline Kota Kinabalu & $\begin{array}{l}0.063 \\
(0.087)\end{array}$ & & & & \\
\hline Number of observations & 300 & 100 & 70 & 50 & 80 \\
\hline Adjusted R-squared & 0.092 & 0.280 & 0.329 & 0.231 & 0.044 \\
\hline
\end{tabular}

Notes: Significance levels: ${ }^{*} p<.1,{ }^{* *} p<.05,{ }^{* * * *} p<.01$. Other control variables are omitted here for simplicity 
Table 5. Two-stages estimates of the effect of green products consumption behavior and environmental awareness

\begin{tabular}{lll}
\hline $\begin{array}{l}\text { Second stage estimates: } \\
\text { Dependent variable: Environmental awareness }\end{array}$ & Model 1 & Model 2 \\
\hline Green products consumption behavior & 1.474 & $1.001^{* *}$ \\
& $(0.969)$ & -0.050 \\
Government policy & -0.204 & $(0.164)$ \\
& $(0.319)$ & \\
First stage estimates: & & $0.102^{*}$ \\
Dependent variable: Green products consumption behavior & $0.099^{*}$ & $(0.056)$ \\
Green products consumptionexpectations & $(0.058)$ & $0.146^{* *}$ \\
Green products consumptionbeliefs & & $(0.063)$ \\
& & $0.315^{* * *}$ \\
Government policy & $0.326^{* * *}$ & $(0.074)$ \\
Wu-Hausmann F-statistics (p-value) & $(0.072)$ & 0.003 \\
F-statistics & 0.033 & $4.129^{* *}$ \\
Sargan chi-squared statistics (p-value) & $3.033^{*}$ & 0.417 \\
\hline Notes: Significan
\end{tabular}

Notes: Significance levels: ${ }^{*} p<.1,{ }^{* *} p<.05,{ }^{* * *} p<.01$.Other control variables are omitted here for simplicity.

A low level of green product consumption behavior on statement item (1) may suggest that Go Green campaigns should focus on this. For instance, it should highlight the short-term and long-term benefits of green product consumption and its importance to be practiced now. Ali et al. (2016) indicate that there is still a low level of green technology consumption in Sabah, particularly in the construction sectors. As Sabah is a region with growing and rapid construction projects, the government should take into account the implementation of green technology to preserve its environment in short and long-term periods. Ojo and Fauzi (2020) and Radu (2016) among others have shown the importance of green technology in improving institutional environmental awareness.

In contrast, a high level of green products consumption behavior may suggest that people in Sabah start to adapt with no plastic bag campaign in supermarkets, buy organic ingredients, and support goods from natural materials such as rattan bags. Sabah wealthiness in natural materials may be the driving force for green products industry development in the region. Hence, it is recommended for people in Sabah and Malaysia in general, to implement and support green products or eco-friendly products such as a Green Buddy industry in Sabah who has introduced various biodegradable products at affordable prices. The government and authorities also should play their role in promoting the products via reachable media social. Suki et al. (2020) show that social globalization may help to reduce the issues of environmental. In addition, Lasuin and Ching (2014) show that environmental awareness and self-image of environmentally-friendly people are significant factors to increase green product consumption among youngsters in Sabah. Similarly, Ogiemwonyi et al. (2020) indicate that green culture significantly affects consumers' green behaviors.

Table 4 shows the estimates of the relationship between green product consumption and environmental awareness for all samples and by region. Overall, we can see that the impact of green product consumption is positive and statistically significant on environmental awareness especially in Kota Kinabalu. This result is in line with the utility maximization theory and study for instance by Rustam et al. (2020). However, it contradicts Ojo and Fauzi (2020) and $\mathrm{Xu}$ et al. (2020) studies. Hence, in the next section, we address this issue using the two-step least squares method to examine potential reverse causality effects in our findings.

The impact of green product consumption behaviour is greater than the government policy such as on green technology and climate change. It suggests a policy implication that initiatives on social practices such as introducing eco-friendly products should be continued to improve people awareness on protecting the environment. This coincides with the suggestion of Suki et al. (2020) study, who highlight the greater implication of social rather than economic aspects in mitigating the environmental issues. On the other hand, lack of knowledge on green technology benefits may also be one of the potential explanations for a low impact of green technology in Sabah (Jainudin et al. 2017).

Regarding other explanatory variables, only age groups, marital status, and areas show significant effects on environmental awareness proportions. In particular, males in Lahad Datu tend to better accept the environmentallyfriendly campaign compared to people in Tawau. In addition, unmarried adults in Kota Kinabalu, have a better awareness of the importance of protecting the environment compared to married persons. These findings are in line with studies by Lasuin \& Ching (2014) and $\mathrm{Xu}$ et al. (2020), among others. Xu et al. (2020) in their study show that the majority of an individual at 20 to 40 years tend to consume sustainable products. They suggest that subjective norm and perceived behavior control are highly correlated with consumers' purchasing intention-endogeneity effects.

Table 5 shows the results of two-step least squares estimation in addressing potential bias estimates of Table 4 . It also aims to examine whether there is an attitude behavior gap of green product consumption in Sabah as we regard that factors such as expectation and beliefs are 
potential unobserved factors for the potential endogenous variable. We can see that individuals' green attitude in Sabah is statistically contributable to their green product consumption behaviours. The results indicate that there is endogeneity bias in the baseline model with statistically significant effects of the endogeneity bias test and strong effects of instruments in particular for model 2. Results from the estimate also suggest that there is a lack of gap between green consumer attitudes and behaviors in Sabah. This finding is in line with studies by Ojo and Fauzi (2020) and Ogiemwonyi et al. (2020) who found that attitude and culture had a positive and significant impact on green behaviors in Malaysia. It recommends that the government and other regions with almost the same issues and socioeconomic conditions embed green product consumption attitudes to enhance its practices and improve environmental awareness among the public.

Finally, further studies are suggested to examine the relationship between consumer behaviors towards green products and other initiatives by socioeconomic status to suggest appropriate policy responses. Also, a robustness analysis using alternative methods or other instruments are suggested to be examined. It may help the government to exclusively revise and achieve its environmental aspiration to conserve biodiversity while improving economic development, for instance through foreign investment as discussed by Rustam et al. (2019), in Sabah state in particular.

\section{ACKNOWLEDGEMENTS}

The authors would like to thank the Universiti Malaysia Sabah for providing the fund for publication. The corresponding author is responsible for the remaining errors.

\section{REFERENCES}

Ali ANA, Jainudin NA, Tawie R, Jugah I. 2016. Green initiatives in Kota Kinabalu construction industry. Procedia-Soc Behav Sci 224: 626631. DOI: $10.1016 /$ j.sbspro.2016.05.453.

Belz FM, Peattie K. 2012. Sustainability Marketing: A Global Perspective, 2nd ed. John Wiley and Sons, New York.

Cole MA, Rayner AJ, Bates JM. 1997. The environmental Kuznets curve: An empirical analysis. Environ Dev Econ 2 (4): 401-416. DOI: 10.1017/S1355770X97000211.

Culas RJ. 2007. Deforestation and the environmental Kuznets curve: An institutional perspective. Ecol Econ 61 (2-3): 429-437. DOI: 10.1016/j.ecolecon.2006.03.014.

Deaton A, Muellbauer J. 1980. Economics and Consumer Behaviour. Cambridge University Press, UK.

Dulal HB, Shah KU, Sapkota C. 2012. Reducing emissions from deforestation and forest degradation (REDD) projects: lessons for future policy design and implementation. Int J Sustain Dev World Ecol 19 (2): 116-129. DOI: 10.1080/13504509.2012.654410.

Gujarati DN, Porter DC. 2008. Basic Econometrics, 5th ed. McGraw-Hill Education, New York.

Hahn J, Hausman J. 2002. A new specification test for the validity of instrumental variables. Econometrica 70 (1): 163-189. DOI: $10.1111 / 1468-0262.00272$

Hausman JA. 1978. Specification tests in econometrics. Econometrica 46 (6): 1251-1271. DOI: $10.2307 / 1913827$.
Jainudin NA, Jugah I, Ali ANA, Tawie R. 2017. The acceptance of green technology: A case study in Sabah development corridor. AIP Conf Proc 1875. DOI: 10.1063/1.4998372.

Krejcie RV, Morgan DW. 1970. Determining sample size for research activities. Educat Psychol Measur 30: 607-610. DOI: 10.1177/001316447003000308.

Lasuin CA, Ching NY. 2014. Factors influencing green purchase intention among university students. Malay J Bus Econ 1 (2): 1-14.

Liwan A, Surianshah NSB, Surianshah SB, Hwang JYT. 2019. Tahap kesedaran awam terhadap perubahan iklim di Sabah. Seminar Bencana Alam. Sabah State, Malaysia.

Martin S, Rieple A, Chang J, Boniface B, Ahmed A. 2015. Small farmers and sustainability: Institutional barriers to investment and innovation in the Malaysian palm oil industry in Sabah. J Rural Stud 40: 46-58. DOI: 10.1016/j.jrurstud.2015.06.002.

Ogiemwonyi O, Harun AB, Alam MN, Karim AM, Tabash MI, Hossain MI, Aziz S, Abbasi BA, Ojuolape MA. 2020. Green product as a means of expressing green behaviour: A cross-cultural empirical evidence from Malaysia and Nigeria. Environ Technol Innov 20: 101055. DOI: 10.1016/j.eti.2020.101055.

Ojo AO, Fauzi MA. 2020. Environmental awareness and leadership commitment as determinants of IT professionals engagement in Green IT practices for environmental performance. Sustain Prod Consum 24: 298-307. DOI: 10.1016/j.spc.2020.07.017.

Peterson AL, Gallagher LA, Huberman D, Mulder I. 2012. Seeing REDD: Reducing emissions and conserving biodiversity by avoiding deforestation. J Sustain For 31 (1-2): 29-58. DOI: 10.1080/10549811.2011.565710.

Radu LD. 2016. Determinants of green ICT adoption in organizations: A theoretical perspective. Sustainability 8 (731): 1-16. DOI: 10.3390/su8080731.

Rustam A, Wang Y, Zameer H. 2020. Environmental awareness, firm sustainability exposure and green consumption behaviors. J Clean Prod 268: 122016. DOI: 10.1016/j.jclepro.2020.122016.

Rustam A, Wang Y, Zameer H. 2019. Does foreign ownership affect corporate sustainability disclosure in Pakistan? A sequential mixedmethods approach. Environ Sci Pollut Res 26 (30): 31178-31197. DOI: $10.1007 / \mathrm{s} 11356-019-06250-3$.

Samii C, Lisiecki M, Kulkarni P, Paler L, Chavis L. 2014. Effects of Payment for Environmental Services (PES) on deforestation and poverty in low and middle-income countries: A Systematic review. Campbell Syst Rev 10 (1): 1-95. DOI: 10.4073/csr.2014.11.

Sargan JD. 1958. The estimation of economic relationships using instrumental variables. Econometrica 26 (3): 393-415. DOI: $10.2307 / 1907619$.

Sekaran U, Bougie R. 2014. Research Methods for Business: A SkillBuilding Approach, 6th ed. John Wiley \& Sons, Inc., New York.

Snaddon JL, Willis KJ, Macdonald DW. 2013. Biodiversity: Oil-palm replanting raises ecology issues. Nature 502: 170-171. DOI: 10.1038/502170d.

Stern DI. 2004. The Rise and Fall of the Environmental Kuznets Curve. World Dev 32 (8): 1419-1439. DOI: 10.1016/j.worlddev.2004.03.004

Stock JH, Wright JH, Yogo M. 2002. A survey of weak instruments and weak identification in generalized method of moments. J Bus Econ Stat 20 (4): 518-529. DOI: 10.1198/073500102288618658.

Suki NM, Sharif A, Afshan S, Suki NM. 2020. Revisiting the environmental Kuznets Curve in Malaysia: The role of globalization in sustainable environment. J Clean Prod 264: 1-10. DOI: 10.1016/j.jclepro.2020.121669.

Wen PP, Sidik MJ. 2011. Impacts of rainfall, temperature and recent El Ninos on fisheries and agricultural products in The West Coast of Sabah. Borneo Sci 28 (March): 73-85.

Wendling ZA, Emerson JW, De Sherbinin A, Esty DC. 2020a. Environmental Performance Index 2020. Yale Center for Environmental Law \& Policy, New Haven, CT.

Wendling ZA, Emerson JW, De Sherbinin A, Esty DC. 2020 b. Environmental Performance Index 2020 Malaysia. Yale Center for Environmental Law \& Policy, New Haven, CT.

Williams R. 2020. Ordinal Independent Variables. In: Atkinson P, Delamont S, Cernat A, Sakshaug JW, Williams RA (eds) Research Methods Foundations. SAGE Publications Ltd., London. DOI: $10.4135 / 9781526421036938055$

World Economic Forum. 2021. A decade left: Confronting runaway climate threat. World Economic Forum, Davos, Switzerland. weforum.org 
Wu DM. 1974. Alternative tests of independence between stochastic regressors and disturbances: Finite sample results. Econometrica 42 (3): 529-546. DOI: 10.2307/1911789.

Xu X, Wang S, Yu Y. 2020. Consumer's intention to purchase green furniture: Do health consciousness and environmental awareness matter? Sci Total Environ 704 (96): 1-9. DOI: 10.1016/j.scitotenv.2019.135275.

Yusof A. 2021. Sabah sea gypsies grapple with dwindling fish catch, sinking villages as climate change threatens way of life. Channel News Asia. www.channelnewsasia.com. 